\title{
Transcriptional response of Candida albicans biofilms following exposure to 2-amino-nonyl-6-methoxyl- tetralin muriate
}

\author{
Rong-mei LIANG ${ }^{1,2}$, Yong-bing CAO ${ }^{1, *}$, You-jun ZHOU ${ }^{3}$, Yi XU $^{1}$, Ping-hui GAO ${ }^{1}$, Bao-di DAI ${ }^{1}$, Feng YANG ${ }^{4}$, Hui TANG $^{3}$, Yuan- \\ ying JIANG ${ }^{1, *}$ \\ ${ }^{1}$ Department of Pharmacology, School of Pharmacy, Second Military Medical University, Shanghai 200433, China; ${ }^{2}$ Department of \\ Pharmacy, General Hospital of Chengdu Military Command Region, Chengdu 610083, China; ${ }^{3}$ Department of Medicinal Chemistry, \\ School of Pharmacy, Second Military Medical University, Shanghai 200433, China; ${ }^{4}$ Department of Pharmacology, School of Phar- \\ macy, China Pharmaceutical University, Nanjing 210009, China
}

\begin{abstract}
Aim: To identify changes in the gene expression profile of Candida albicans ( $C$ albicans) biofilms following exposed to 2-amino-nonyl-6methoxyl-tetralin muriate $(10 \mathrm{~b})$ and clarify the mechanism of $10 \mathrm{~b}$ against $C$ albicans biofilms.

Methods: Anti-biofilm activity of 10b was assessed by tetrazolium (XTT) reduction assay and the action mechanism against biofilms was investigated by cDNA microarray analysis and real-time RT-PCR assay.

Results: Ten differentially expressed genes were directly linked to biofilm formation and filamentous or hyphal growth (eg, NRG1, ECE1 and CSA1). Decreased gene expression was involved in glycolysis (eg, HXK2 and PFK1) and antioxidant defense (eg, SOD5), while increased gene expression was associated with enzymes that specifically hydrolyzed $\beta-1,3$ glucan (XOG1), and with lipid, fatty acid and sterol metabolism (eg, SLD1, ERG6 and ERG2). Functional analysis indicated that addition of anti-oxidant ascorbic acid reduced inhibitory efficiency of $10 \mathrm{~b}$ on mature biofilm.

Conclusion: Inhibition of 10b on biofilm formation possibly depends on impairing the ability of $C$ albicans to change its morphology via altering the expression of biofilm formation genes. Mitochondrial aerobic respiration shift and endogenous ROS augmentation might be a major contribution to reduce mature biofilm metabolic activity. The data may be useful for the development of new strategies to reduce the incidence of device-associated infections.
\end{abstract}

Keywords: 2-amino-nonyl-6-methoxyl-tetralin muriate; anti-biofilm activity; action mechanism; microarray analysis; Candida albicans

Acta Pharmacologica Sinica (2010) 31: 616-628; doi: 10.1038/aps.2010.33; published online 12 April 2010

\section{Introduction}

$C$ albicans is a dimorphic species capable of changing its morphology from the yeast form to the hyphal form, an all-important process to form mature biofilms and a transition critical to its pathogenesis ${ }^{[1-3]}$. Biofilm structure impairs the action of phagocytic cells from the immune system and antimicrobial agents $^{[4-6]}$, which are notoriously difficult to eradicate as well as an important source of many recalcitrant infections.

Biofilm development occurs in three phases over a period of $24-48 \mathrm{~h}^{[7-9]}$. The initial phase begins with adherence of single cells to the substratum. Second, attached cells proliferate to form microcolonies and begin to deposit an extracellular

\footnotetext{
* To whom correspondence should be addressed.

E-mail ybcao@vip.sina.com (Yong-bing CAO)

jiangyysmmu@163.com (Yuan-ying JIANG)

Received 2009-12-24 Accepted 2010-02-24
}

matrix. Finally, once cells reach confluency, the network of yeast cells transits to filamentous (pseudohyphal and hyphal) forms, which become encased in the exopolymeric matrix. Baillie and Douglas ${ }^{[10,11]}$ reported that slow growth of microorganisms, presumably due to some form of nutrient limitation, may contribute to mature biofilm resistance.

Beta-1,3 glucan is thought to be the main component of the three-dimensional matrix surrounding biofilm cells and closely tied to biofilm formation ${ }^{[12]}$. Nett $e a l^{[13]}$ showed that elevated beta-1,3 glucan levels were characteristic of biofilm cells as compared to planktonic free-living $C$ albicans cells. A complex network of signaling pathways regulates yeasthyphal morphogenesis. It is known that several signaling pathways, including Cph1-mediated mitogen-activated protein kinase and Efg1-mediated cyclic AMP/protein kinase A, participate in the regulation of morphological transition ${ }^{[14,15]}$. These multiple pathways in conjunction with the pathway- 
specific transcription factors regulate the expression of hyphaspecific genes, including ECE1, HWP1, HYR1, ALS1, ALS3, RBT1, RBT4, and HGC1 ${ }^{[16-21]}$. Hyphal development is negatively regulated by transcriptional repressors Tup1, Nrg1, Sfl1, and Rfg1 ${ }^{[22-25]}$. Sfl1 has a dual function in filamentous growth of $C$ albicans: it acts as a repressor of hyphal development antagonizing activation of Flo8 but functions as an activator releasing from inhibition of Flo8 in the matrix at low temperature. Rfg1 is a second DNA-binding protein that targets Tup1 to promoters of hypha-specific genes. Tup1 functions with DNA binding proteins Nrg1 and Rfg1 as a transcription regulator to repress the expression of hypha-specific genes. Nrg1 is a zinc finger DNA-binding protein that represses hyphaspecific genes in a Tup1-dependent manner, making a major contribution to the repression of hyphal development ${ }^{[26]}$.

Biomaterial infections are an increasingly alarming problem. Given their intrinsic recalcitrance to conventional therapies, new methods of examining these infections and a new class of antifungal drugs must be explored. 2-Amino-nonyl-6-methoxyl-tetralin muriate $(10 \mathrm{~b})$, a 2-aminotetralin derivate, was synthesized as a novel chemical structural antifungal agent (Figure 1). In our previous study, we found that $10 \mathrm{~b}$ had antibiofilm activity. It has been demonstrated that farnesol was an extracellular quorum sensing molecule in the dimorphic fungus $C$ albicans ${ }^{[27]}$, which inhibits the yeast to mycelium dimorphic transition and prevents biofilm formation ${ }^{[28]}$. Therefore, we selected farnesol as positive control to investigate the effect of $10 \mathrm{~b}$ on $\mathrm{C}$ albicans biofilms formation. The aim of the work presented here was to further investigate the mechanism of action of $10 \mathrm{~b}$ against $\mathrm{C}$ albicans biofilms at molecular level.

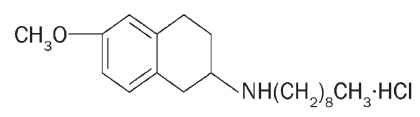

Figure 1. Chemical structure of 2-amino-nonyl-6-methoxyl-tetralin muriate (10b).

\section{Materials and methods Antifungal agents}

Antifunal reagents used in the present experiment included farnesol (Alfa Aesar, A Johnson Matthey Co, Ward Hill, USA); miconazole (MCZ, Pfizer-Roerig Pharmaceuticals, New York, USA); 10b (Department of Medicinal Chemistry, School of Pharmacy, Second Military Medical University, Shanghai, China); and stock solutions of various concentrations in methanol (Sigma).

\section{C albicans strains and growth conditions}

C albicans SC5314 was used throughout this study. C albicans cells were propagated in yeast-peptone-dextrose (YPD) medium $(1 \% w / v$ yeast extract, $2 \% w / v$ peptone, $2 \% w / v$ dextrose). Blastospores were harvested and washed twice in 0.15 mol/L phosphate-buffered saline (PBS; pH 7.2). The cells were then suspended in RPMI-1640 medium (RPMI 1640 supplemented with L-glutamine and buffered to $\mathrm{pH} 7.0$ with morpholinepropanesulfonic acid (MOPS)) and counted in a haemocytometer and adjusted to $1.0 \times 10^{6}$ colony forming unit (CFU) /mL.

\section{In vitro anti-biofilm activity assay}

$C$ albicans bioflm metabolic activity was assessed using the XTT reduction assay as described previously ${ }^{[29]}$. The principle is based upon the reduction of tetrazolium to tetrazolium formazan by mitochondrially active yeasts in the presence of menadione, an electron-coupling agent. Briefly, XTT (Sigma Chemical Co) at $0.5 \mathrm{mg} / \mathrm{mL}$ was added with menadione (10 $\mathrm{mmol} / \mathrm{L}$ in acetone) to a final concentration of $1 \mu \mathrm{mol} / \mathrm{L}$ in PBS. A $200 \mu \mathrm{L}$ aliquot of XTT-menadione was added to each well and incubated in the dark at $37^{\circ} \mathrm{C}$ for $2 \mathrm{~h}$. Any colorimetric change (a direct reflection of metabolic activity of the biofilms) was measured in a microtitre plate reader (Multiskan MK3) at $492 \mathrm{~nm}$.

Biofilms were formed in selected 96-microtitre plates. Following the initial $1 \mathrm{~h}$ adhesion, the medium was aspirated and then washed thoroughly twice with sterile PBS before the addition of fresh RPMI-1640 medium containing different concentrations of antifungal agents and incubated for another $48 \mathrm{~h}$ at $37^{\circ} \mathrm{C}$. A series of antifungal-free wells was also included as controls. Sessile $\mathrm{MIC}_{50}$ were determined at $50 \%$ inhibition $\left(\mathrm{SMIC}_{50}\right)$ compared with drug-free control wells using XTT reduction assay.

To determine the effect of $10 \mathrm{~b}$ on adhesion of planktonic cells, antifungal drugs were added to a standardized suspension at zero time (preincubation) before it was added to a 96-microtiter plate. The plate was incubated for $90 \mathrm{~min}$ at $37^{\circ} \mathrm{C}$. Knowing that adherent populations on the substratum do not form a structurally differentiated community (biofilm) during this period of time $\mathrm{e}^{[30]}$, we chose $90 \mathrm{~min}$ as the incubation time of the adhesion assay. To determine the effect of $10 \mathrm{~b}$ on mature biofilms, mature biofilms ( $48 \mathrm{~h}$ ) formed as above in the absence of antifungal drugs were added with fresh RPMI1640 medium containing different concentrations of antifungal drugs. The plates were incubated at $37^{\circ} \mathrm{C}$ for $3,6,12$, and 24 h.

\section{Confocal laser scanning microscopy}

Confocal laser scanning microscopy (CLSM) was performed as described in the literature ${ }^{[31]}$ to demonstrate the inhibitory effect of $10 \mathrm{~b}$ on biofilm formation. Formation of $C$ albicans SC5314 biofilms was achieved by adding $4 \mathrm{~mL}$ standardized cell suspension to six-well plates containing plastic disks. Following $10 \mathrm{~b}$ exposure and biofilm formation, the disks were removed and transferred to new six-well culture plates and incubated for $45 \mathrm{~min}$ at $37^{\circ} \mathrm{C}$ in $4 \mathrm{~mL}$ PBS containing the fluorescent stains FUN-1 $(10 \mu \mathrm{mol} / \mathrm{L}$; Molecular Probes, Eugene, Oreg) and concanavalin A-Alexa Fluor 488 conjugate (ConA; $25 \mu \mathrm{g} / \mathrm{mL}$; Molecular Probes). FUN-1 (excitation wavelength, $543 \mathrm{~nm}$; emission wavelength, $560 \mathrm{~nm}$; long-pass filter) is converted to an orange-red cylindrical intravacuolar structure by metabolically active cells, while ConA (excitation 
wavelength, $488 \mathrm{~nm}$; emission wavelength, $505 \mathrm{~nm}$; long-pass filter) binds to glucose and mannose residues of cell wall polysaccharides and emits a green fluorescence. After incubation with the dyes, the disks were flipped and the stained biofilms were observed with a Leica TCS sp2 CLSM equipped with argon and HeNe lasers.

\section{RNA isolation and microarray hybridization}

For RNA isolation experiments, cells were added to $25 \mathrm{~mL}$ portions of RPMI-1640 medium in $75-\mathrm{cm}^{2}$ tissue culture flasks with vented caps. The flasks were incubated statically for $1 \mathrm{~h}$ to allow initial adherence of the cells, and then the medium was decanted and replaced with $25 \mathrm{~mL}$ portions of fresh RPMI-1640 medium containing $10 \mu \mathrm{mol} / \mathrm{L} \mathrm{10b.} \mathrm{We} \mathrm{chose}$ this $10 \mathrm{~b}$ concentration because it still maintained an inhibitory effect on biofilm formation and allowed for recovery of a sufficient cellular mass for RNA extraction. The flasks were then incubated statically for $48 \mathrm{~h}$ at $37^{\circ} \mathrm{C}$. A $10 \mathrm{~b}$-free control was also included. Total RNA was isolated by the hot phenol method ${ }^{[32]}$ and purified with a NecleoSpin ${ }^{\circledR}$ Extract II kit (Machery-Nagel Corp, Germany) following the manufacturer's protocol. A $7925 \mathrm{C}$ albicans genome 70-mer oligonucleotide microarray was obtained from CapitalBio Corporation (Beijing, China). A 1- $\mu$ g sample of total RNA was used for preparing fluorescent dye-labeled cDNA by the linear mRNA amplification procedure as described ${ }^{[33]}$. A DNADNA hybridization protocol was used to replace RNA-DNA hybridization in the present study for the sake of reducing cross-hybridization $^{[34]}$. The labeled cDNAs were dissolved in $80 \mu \mathrm{L}$ hybridization solution [ $3 \times \mathrm{SSC}, 0.2 \%(w / v)$ SDS, $5 \times$ Denhardt's solution, $25 \%(v / v)$ formamide] and denatured at $95{ }^{\circ} \mathrm{C}$ for $3 \mathrm{~min}$ before hybridization. A sample of the mixed hybridization buffer was placed onto a microarray slide and covered with a glass coverslip. Hybridization was done with a BioMixer ${ }^{\mathrm{TM}}$ II (CapitalBio Corp, China). After hybridization, the slides were washed with washing solution $1(2 \times \mathrm{SSC}, 0.2 \%$ SDS) and then with washing solution $2(2 \times \mathrm{SSC})$ at $42{ }^{\circ} \mathrm{C}$ for $4 \mathrm{~min}$. Self-hybridization of the control sample was used to evaluate the system noise.

The microarrays were scanned with a LuxScan ${ }^{\mathrm{TM}}$ 10KAscanner (CapitalBio Corp, China) at two wavelengths to detect emissions from both $\mathrm{Cy} 3$ and $\mathrm{Cy} 5$. The image obtained was analyzed with LuxScan ${ }^{\mathrm{TM}} 3.0$ software (CapitalBio Corp, China). Normalization was done on the basis of a Lowess program $^{[35]}$. The ratio of Cy5 to Cy3 was calculated for each location on each microarray. To minimize artifacts that arose from low expression values, only genes with raw intensity values $>800$ counts for both $\mathrm{Cy} 3$ and $\mathrm{Cy} 5$ were chosen for analysis. A "one class" method for the analysis of microarray software (SAM) was used to identify significantly differentially expressed genes. Genes with a false discovery rate $(\mathrm{FDR})<5 \%$, $q$-value $<1 \%$ and variation of at least 2-fold in SC5314 biofilms following $10 \mathrm{~b}$ exposure were identified as significantly differentially expressed genes in two independent experiments. Differentially expressed genes were clustered hierarchically by Gene Cluster 3.0 (Stanford University). DNA sequences were annotated on the basis of the results of BlastN and BlastX searches using the sequencing database of Stanford University (Palo Alto, CA) (http://www-sequence.stanford.edu/ group/candida/), GenBank (http://www.ncbi.nlm.nih.gov/ BLAST/), and CandidaDB database (http://genolist.pasteur. fr/CandidaDB/).

The entire arrary data have been deposited in the NCBI gene Expression Omnibus (GEO) (http://www. ncbi.nlm.nih. gov) and are aceesible through GEO series accession number GSE19226.

\section{Quantitative real-time RT-PCR assay}

Real-time RT-PCR was used to confirm microarray results of gene expression changes. An aliquot of the RNA preparations used in the microarray experiments was saved for this followup study. Moreover, duplicate independent experiments were conducted to isolate RNA samples according to the protocol described above. First-strand cDNAs were synthesized from 1 $\mu \mathrm{g}$ total RNA in a $20 \mu \mathrm{L}$ reaction volume using the cDNA synthesis kit for RT-PCR (TaKaRa Biotechnology, Dalian, China) in accordance with the manufacturer's instructions. Real-time PCR reactions were performed with SYBR Green I (TaKaRa), using ABI 7500 Real-Time PCR system (Applied Biosystems Co, California, USA). Gene-specific primers were designed using Discovery Studio Gene software (Accelrys, Inc). The thermal cycling conditions comprised an initial step at $95{ }^{\circ} \mathrm{C}$ for $1 \mathrm{~min}$, followed by 40 cycles at $95{ }^{\circ} \mathrm{C}$ for $10 \mathrm{~s}, 55^{\circ} \mathrm{C}$ for $20 \mathrm{~s}$, and $72{ }^{\circ} \mathrm{C}$ for $30 \mathrm{~s}$. Change in SYBR Green I fluorescence in every cycle was monitored by the system software, and the threshold cycle $\left(\mathrm{C}_{\mathrm{T}}\right)$ was measured. Using $18 \mathrm{~S}$ rRNA as the internal control, gene expression of SC5314 biofilms treated by $10 \mathrm{~b}$ relative to that without treatment was calculated using the formula $2^{-\Delta \Delta C T}$, where $\Delta C_{T}$ is the $C_{T}$ value of genes of interest minus that of the internal control, and $\triangle \triangle C_{T}$ is the mean $\triangle C_{T}$ value of SC5314 biofilms treated by $10 \mathrm{~b}$ minus that without treatment. Primer sequences used in real-time RT-PCR assay are listed in Table 1.

\section{Statistics}

Experiments were performed at least three times. Data are presented as 'mean \pm standard deviations' and analyzed using the Student's $t$ test where indicated.

\section{Results}

\section{In vitro anti-biofilm activity of $10 \mathrm{~b}$}

$10 \mathrm{~b}$ had been reported to have great antifungal activity ${ }^{[36,37]}$, but its dramatic anti-biofilm activity was unexpected. CLSM showed that normal $C$ albicans biofilm exhibited a typical three-dimensional structure and composed mainly of true hyphae and pseudohyphae (Figure 2A). When cells were preincubated with $10 \mu \mathrm{mol} / \mathrm{L}$ farnesol at $0 \mathrm{~h}$ incubation time, biofilm development can not be prevented and still composed mainly of true hyphae and pseudohyphae (Figure 2B). However, after preincubation with $0.1 \mu \mathrm{mol} / \mathrm{L} 10 \mathrm{~b}$, the typical architecture of biofilms (intertwining mycelial structures and a basal layer of blastospores) was destructed although 
Table 1. List of primers used for real-time RT-PCR.

\begin{tabular}{|c|c|c|}
\hline Target genes & Primer pairs $\left(5^{\prime}-3^{\prime}\right)^{\text {a) }}$ & Amplicon size (bp) \\
\hline \multirow[t]{2}{*}{$18 \mathrm{~s}$} & (F) TCTTTCTTGATTTTGTGGGTGG & \\
\hline & (R) TCGATAGTCCCTCTAAGAAGTG & 150 \\
\hline \multirow[t]{2}{*}{ ECE1 } & (F) TGACCAAGCACCTACT & \\
\hline & (R) AGCAATGATACCAGCA & 190 \\
\hline \multirow[t]{2}{*}{ NRG1 } & (F) CCATCTCCAGGGCTAAT & \\
\hline & (R) TTCTTCTTGGGTCTTTG & 139 \\
\hline \multirow[t]{2}{*}{ CSA1 } & (F) TCTCAAGTTCCACAAG & \\
\hline & (R) GGTAGAGTTTCCGTAG & 267 \\
\hline \multirow[t]{2}{*}{ ACE2 } & (F) АCTGCTTTCCСАTСCTAT & \\
\hline & (R) TAATCCCATCAATGTTTC & 215 \\
\hline \multirow[t]{2}{*}{ ВMT9 } & (F) TGCTTCTGGCAAGTCAA & \\
\hline & (R) TTCCССТСАСАТААТСC & 105 \\
\hline \multirow[t]{2}{*}{ FGR6-10 } & (F) ACAGTTCTTCGTTTCGG & \\
\hline & (R) TGGTTGGTGTCTCGTTG & 157 \\
\hline \multirow[t]{2}{*}{ SFL1 } & (F) CСССТСААТСGTCATAC & \\
\hline & (R) TGCAGCTCCAGAAGTAG & 200 \\
\hline \multirow[t]{2}{*}{$A D H 1$} & (F) ATCCCTGGTCTTATCTTC & \\
\hline & (R) AACTGGGTAATCCTTGTAG & 184 \\
\hline \multirow[t]{2}{*}{ HXK2 } & (F) CGGTTACTATTTGGGAGA & \\
\hline & (R) TTGGATGGATAAGAGGC & 132 \\
\hline \multirow[t]{2}{*}{ CDC19 } & (F) CTGCTGCTTACGAACA & \\
\hline & (R) AATGGGTAGACACCTCTG & 163 \\
\hline \multirow[t]{2}{*}{ PFK1 } & (F) AGAAACCTGCCTCCTCA & \\
\hline & (R) CCAACCCTAATCTGTCG & 177 \\
\hline \multirow{2}{*}{ GPX2 } & (F) ACTCCACAATACAAAGGTT & \\
\hline & (R) AATACGGGGAAAGTCAC & 164 \\
\hline \multirow[t]{2}{*}{ SOD5 } & (F) ACATTGGCGGTTTATC & \\
\hline & (R) ATTACCTTGAGGAGCA & 185 \\
\hline \multirow[t]{2}{*}{ SOD2 } & (F) AACTTGGCTCCTGTCTC & \\
\hline & (R) TATCACCATTGGCTTTG & 181 \\
\hline \multirow[t]{2}{*}{ XOG1 } & (F) TCCAAGTCTTTGGCTAT & \\
\hline & (R) ACTGAAATGTGGTCGTT & 133 \\
\hline \multirow[t]{2}{*}{ SLD1 } & (F) AGATAGAAGGACCAAGA & \\
\hline & (R) GGAACAAACCCAATACC & 224 \\
\hline \multirow[t]{2}{*}{$D A G 7$} & (F) AAAGGTAACACTAAGATTC & \\
\hline & (R) GTAAAAGTTGTAGATGGG & 119 \\
\hline \multirow[t]{2}{*}{ SFL2 } & (F) TGGGTTCCATAAAGTGAG & \\
\hline & (R) ATAGGTTCGGCATAGATT & 213 \\
\hline \multirow[t]{2}{*}{ GZF3 } & (F) AGTCAAACAAAATGGAAGC & \\
\hline & (R) TTGCCTGATTTGCCTTC & 90 \\
\hline \multirow[t]{2}{*}{$E R G 2$} & (F) GTCTAATGACCCAGTTGT & \\
\hline & (R) TCTTCTTCTGCCTTTGCA & 162 \\
\hline \multirow[t]{2}{*}{ ERG6 } & (F) GCTACCGTTCATGCTCCA & \\
\hline & (R) CCATCACCGACTTCAATA & 164 \\
\hline \multirow[t]{2}{*}{ ERG11 } & (F) GAATCCCTGAAACCAAT & \\
\hline & (R) AGCAGCAGTATCCCATC & 131 \\
\hline ERG24 & (F) GGTGACTTAGCGTGGGT & \\
\hline & (R) GCTGAGCGGAAGATGTA & 143 \\
\hline
\end{tabular}

a) F, forward; R, reverse.

pseudohyphae and true hyphae were observed (Figure 2C). Moreover, the concentration was increased by 10 -fold, the adherent yeast cells were successfully prevented from germination and resulted in scant or nonexistent biofilms (Figure
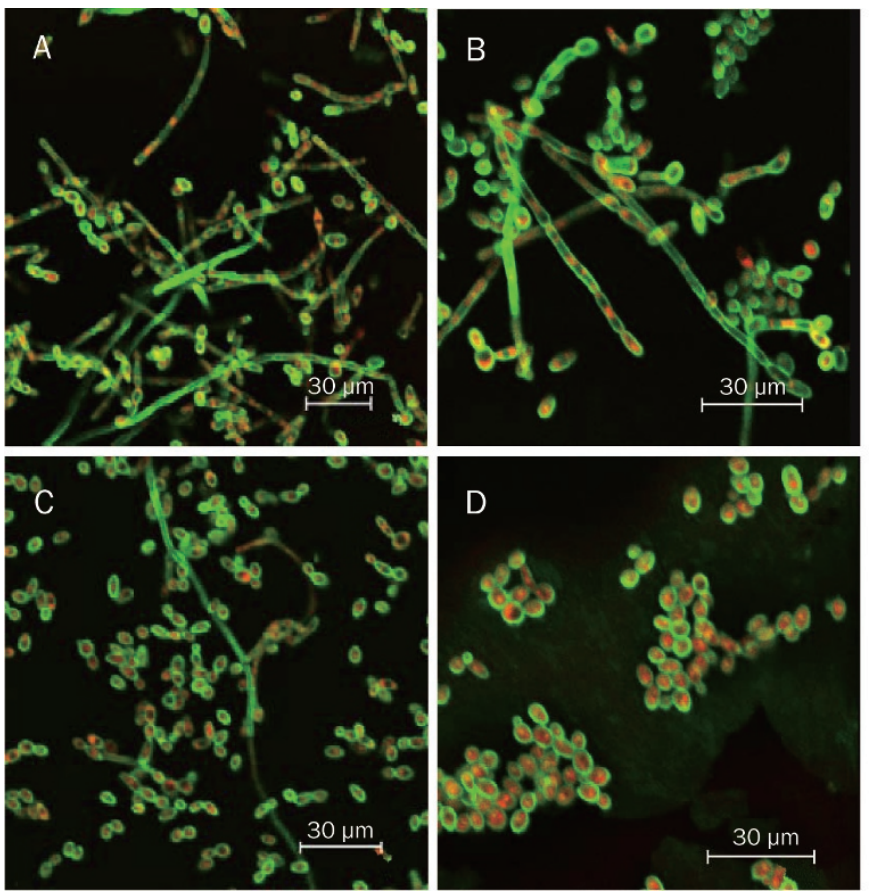

Figure 2. Morphology alteration of $C$ albicans strain after treated with $10 \mathrm{~b}$. Confocal laser scanning microscopy of $C$ albicans biofilms: (A) normal biofilm; (B) cells treated with $10 \mu \mathrm{mol} / \mathrm{L}$ farnesol at $\mathrm{O} \mathrm{h}$ of the incubation time; (C) cells treated with $0.1 \mu \mathrm{mol} / \mathrm{L} 10 \mathrm{~b}$ at $0 \mathrm{~h}$ of the incubation time; (D) cells treated with $1.0 \mu \mathrm{mol} / \mathrm{L} 10 \mathrm{~b}$ at $\mathrm{O} \mathrm{h}$ of the incubation time.

2D). Effect of $10 \mathrm{~b}$ on biofilm formation was also assessed by XTT reduction assay as seen in Figure 3. Over 90\% inhibition of biofilm formation was observed at $10 \mathrm{~b}$ concentrations over $15.63 \mu \mathrm{mol} / \mathrm{L}$. Lower concentrations (7.81 to $15.63 \mu \mathrm{mol} / \mathrm{L}$ ) produced about $50 \%$ inhibition. Moreover, $10 \mathrm{~b}$ used at 1.95 to $3.91 \mu \mathrm{mol} / \mathrm{L}$ was still able to reduce about $30 \%-40 \%$ metabolic activity (Figure 3A). Farnesol was also able to inhibit biofilm formation to some extent but the inhibitory effect was relatively poor (Figure 3B). Less than 55\% inhibitory efficiency of biofilm formation was observed at farnesol concentrations over $15.63 \mu \mathrm{mol} / \mathrm{L}$. No significant inhibition was observed at farnesol concentrations lower than $7.81 \mu \mathrm{mol} / \mathrm{L}$. Furthermore, the $\mathrm{SMIC}_{50}$ value of $10 \mathrm{~b}$ and farnesol were $7.05 \mu \mathrm{mol} / \mathrm{L}$ and $187.50 \mu \mathrm{mol} / \mathrm{L}$, respectively, as determined by XTT reduction assay.

Next, mature $(48 \mathrm{~h})$ biofilms were added with fresh growth medium containing $10 \mathrm{~b}$ and farnesol, and incubated for another 3 to $24 \mathrm{~h}$. As seen in Table 2, 10b at 10 and $50 \mu \mathrm{mol} / \mathrm{L}$ were able to markedly inhibit the metabolic activity of mature biofilms whenever $10 \mathrm{~b}$ was added. Moreover, $10 \mathrm{~b}$ at 50 $\mu \mathrm{mol} / \mathrm{L}$ was able to achieve $62.71 \%$ inhibitory efficiency after incubation for $24 \mathrm{~h}$. However, only farnesol at $50 \mu \mathrm{mol} / \mathrm{L}$ was able to inhibit metabolic activity of mature biofilms significantly. It was worth mentioning that extension of the incubation time increased the efficiency of $10 \mathrm{~b}$ and farnesol in inhibiting the metabolic activity of mature biofilms. 

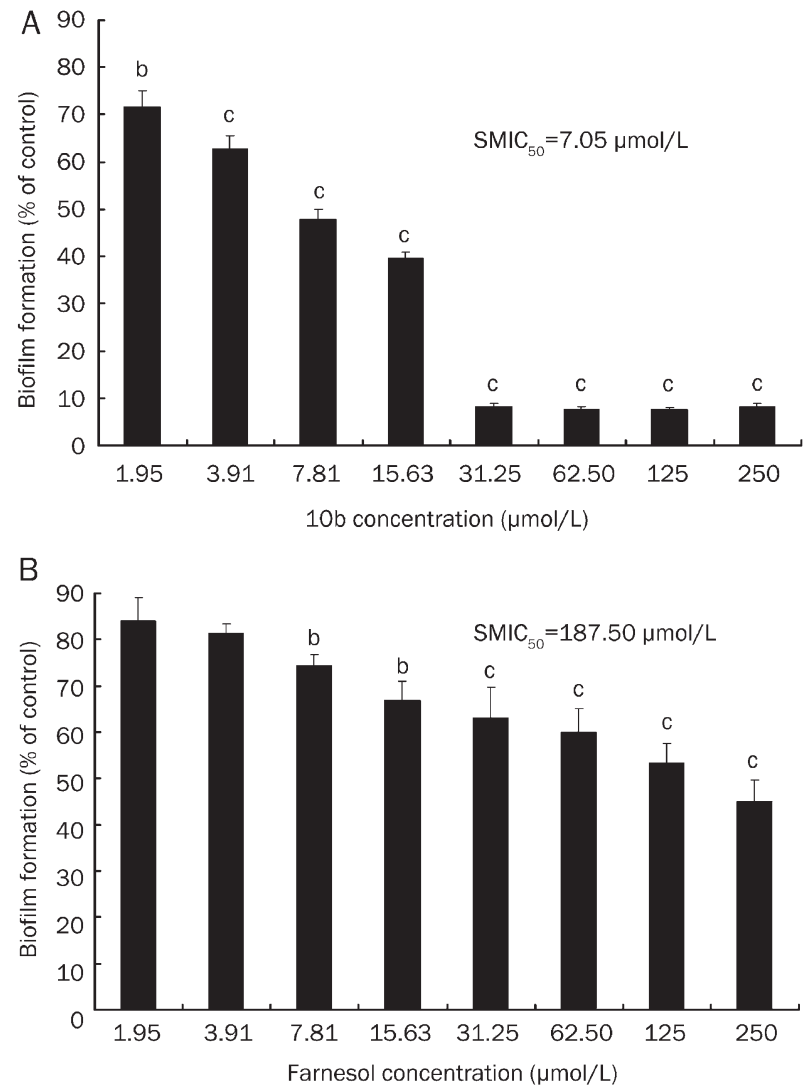

Figure 3. Inhibition of biofilm formation by different concentrations of $10 \mathrm{~b}$ (A) and farnesol (B). Biofilm formation (as measured by XTT reduction) is expressed as a percentage of control biofilms. The data are expressed as mean \pm standard deviation (SD) of three independent experiments. The mean $\pm S D$ of the mean control values $\left(A_{492}\right)$ was $1.083 \pm 0.056$. Statistically significant differences as determined by Student's $t$ test. ${ }^{\mathrm{b}} P<0.05,{ }^{\mathrm{c}} P<0.01$ vs control.

\section{Gene expression responses to $10 \mathrm{~b}$ exposure}

To reveal the mechanism of $10 \mathrm{~b}$ against biofilms at the molecular level, $C$ albicans cDNA microarrays were used to identify changes in gene expression profiles of $C$ albicans SC5314 biofilms following $10 \mathrm{~b}$ exposure in two independent experiments. To avoid dye-associated effects on cDNA synthesis, RNA from the 10b-treated group was labeled with Cy5 and Cy3 separately. In each hybridization experiment, duplicate spots were measured as usual. After statistical analysis of six individual comparisons, only the statistically significant (FDR $<5 \%$, $q$-value $<1 \%$ ) genes whose expression level changed by at least 2 -fold in all data sets were selected. The data generated from these independent microarray experiments reflected a high level of reliability and reproducibility due to the presented ratios obtained from repeated assays of the same samples and of samples from the independent experiments.

A total of 149 differentially expressed genes were found upon exposure to 10b, of which 69 genes showed a decrease in expression, and 80 genes showed an increase in expression (Table 3 and 4). Ten differentially expressed genes were found to relate to biofilm formation, filamentous or hyphal growth. It was noticed that striking up-regulation of NRG1 and marked down-regulation of ECE1 directly related to the inhibition of biofilm formation. One gene related to specifically hydrolyzing beta-1,3 glucan (XOG1) was significantly increased. Ten down-regulated genes were involved in glycolysis (eg, HXK2), fermentation $(e g, A D H 1)$ and active oxygen scavenging (eg, SOD5). Fifteen overexpressed genes were related to the lipid metabolic process. Of them, 13 genes were directly linked to ergosterol biosynthesis, including ERG2, ERG6 and ERG11. Ten genes related to translation were overexpressed following exposure to $10 \mathrm{~b}$. Of them, 2 genes involved in negative regulation of transcription were significantly up-regulated.

\section{Validation of microarray data by real-time RT-PCR}

To validate the expression of genes identified by microarray analysis, real-time RT-PCR was perfomed in 23 genes of interest selected on the basis of their roles in the specific action mechanism of $10 \mathrm{~b}$ (eg, ECE1, NRG1, CSA1, ACE2, BMT9, FGR6-10, SLF1, ADH1, HXK2, CDC19, PFK1, GPX2, SOD5, $S O D 2$ and XOG1) and in the responses independent of mechanism of action (eg, SLD1, DAG7, SFL2, GZF3, ERG2, ERG6, ERG11 and ERG24). Total RNA samples from cells treated or untreated with $10 \mathrm{~b}$ were prepared in parallel for three separate experiments. Real-time RT-PCR reactions were performed in triplicate with independent RNA isolations. It was found that the expression of gene PFK1 was down-regulated as shown by real-time RT-PCR in three independent experiments. In general, there was a good correlation between real-time RT-PCR

Table 2. Effects of $10 \mathrm{~b}$ and farnesol incubated for different times on mature ( $48 \mathrm{~h})$ biofilms.

\begin{tabular}{|c|c|c|c|c|}
\hline \multirow{3}{*}{ Drugs incubation time $(\mathrm{h})$} & \multicolumn{4}{|c|}{ XTT reduction $(\%)^{\text {a) }}$ after further incubation in medium containing compounds at the concentration of: } \\
\hline & \multicolumn{2}{|c|}{$10 b$} & \multicolumn{2}{|c|}{ Farnesol } \\
\hline & $10 \mu \mathrm{mol} / \mathrm{L}$ & $50 \mu \mathrm{mol} / \mathrm{L}$ & $10 \mu \mathrm{mol} / \mathrm{L}$ & $50 \mu \mathrm{mol} / \mathrm{L}$ \\
\hline 3 & $76.68 \pm 4.52^{b}$ & $60.35 \pm 6.17^{c}$ & $108.13 \pm 6.34$ & $79.14 \pm 6.70$ \\
\hline 6 & $73.61 \pm 3.21^{\mathrm{b}}$ & $51.43 \pm 7.81^{\mathrm{c}}$ & $110.47 \pm 10.74$ & $69.23 \pm 1.47^{b}$ \\
\hline 12 & $62.41 \pm 5.27^{c}$ & $47.06 \pm 6.37^{\mathrm{c}}$ & $97.11 \pm 6.01$ & $71.58 \pm 1.76^{b}$ \\
\hline 24 & $58.19 \pm 2.51^{c}$ & $37.29 \pm 3.18^{c}$ & $98.73 \pm 7.05$ & $64.72 \pm 5.97^{\circ}$ \\
\hline
\end{tabular}

a) $10 \mathrm{~b}$ and farnesol were added to mature ( $48 \mathrm{~h}$ ) biofilms and incubation was continued for further 3 to $24 \mathrm{~h}$ at $37^{\circ} \mathrm{C}$. XTT reduction is expressed as a percentage of that of control mature biofilms $(48 \mathrm{~h})$ further incubated for the same time period without the above drugs. The results are mean \pm standard deviations of three independent experiments. ${ }^{b} P<0.05,{ }^{\circ} P<0.01$ vs control. 
Table 3. Genes down-regulated in 10b-grown biofilms compared to biofilms without treatment through two independent experiments.

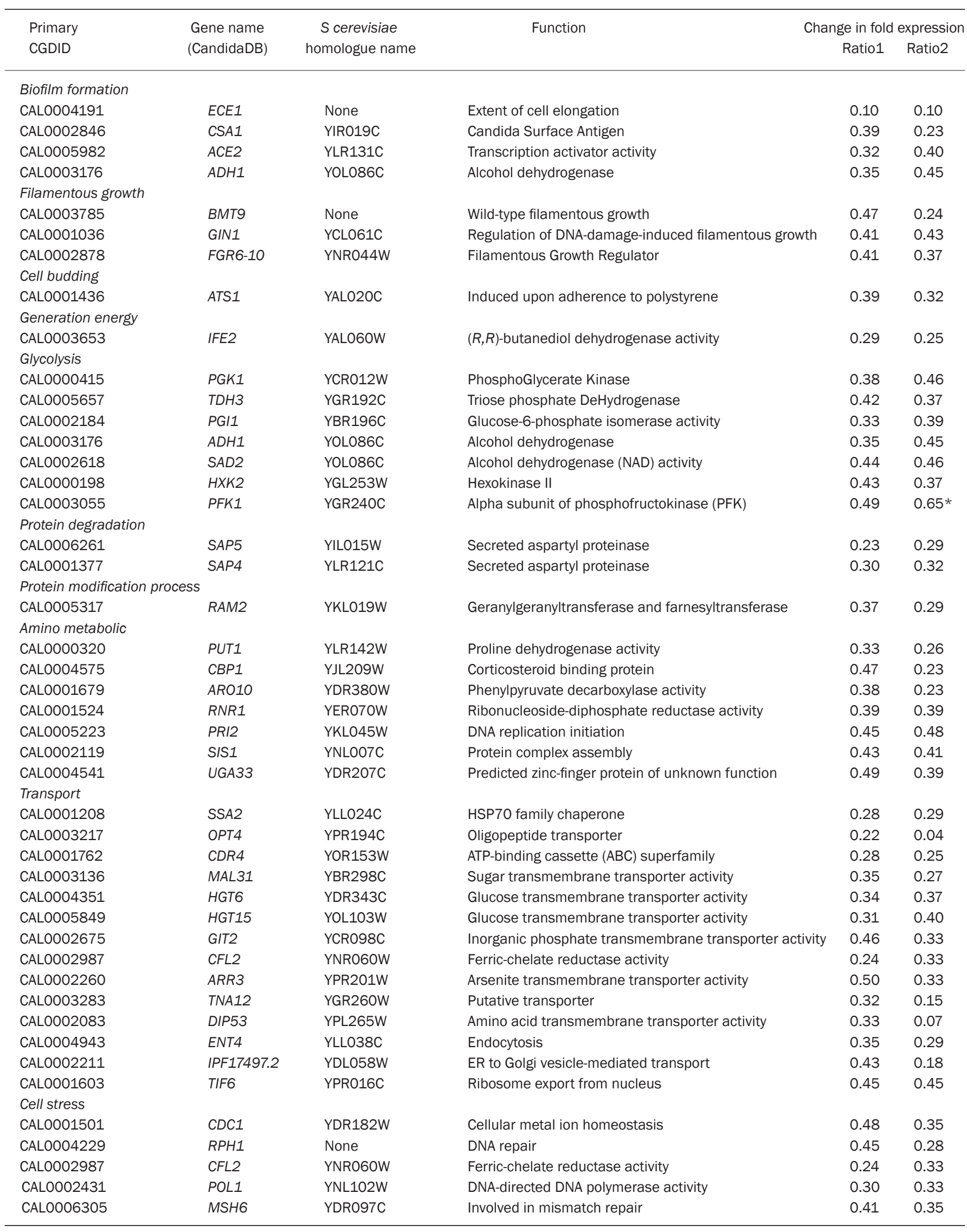




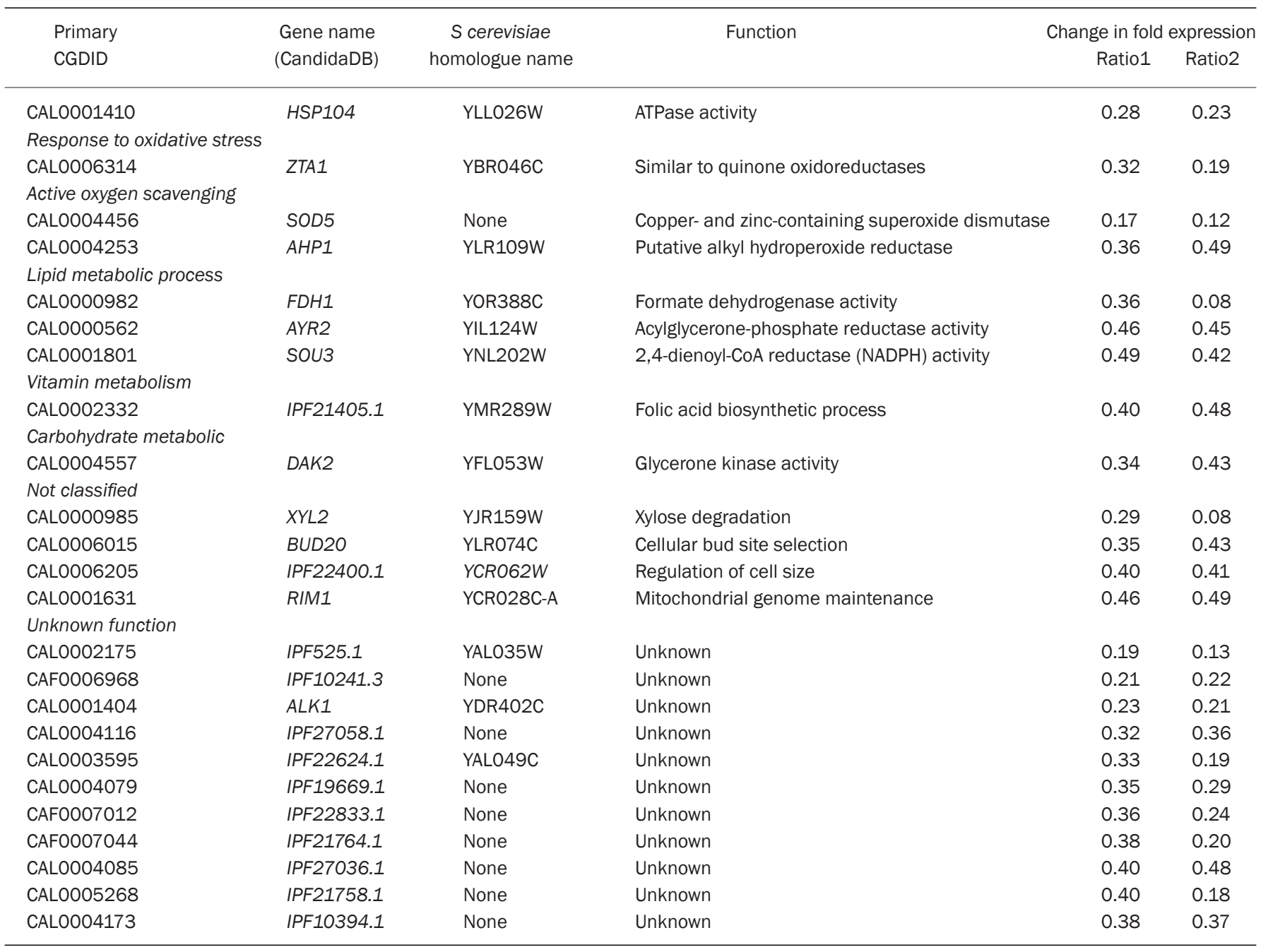

* Real-time RT-PCR verified the expression of the gene down-regulation through three independent experiments.

and microarray data (Figure 4).

\section{Effects of ROS on C albicans biofilms}

According to Pastuer effect, the tricarboxylic acid cycling process might be enhanced because the expression of genes participating in glycolysis was decreased after exposure to $10 \mathrm{~b}$ under aerobic circumstances. Besides, the expression of genes encoded superoxide dismutase (SOD) was also decreased. This might result in augmentation of ROS generation (Figure 5). To assess the role of endogenous ROS against $C$ albicans biofilms, XTT reduction assay was performed to investigate the effects of ROS scavenger, ascorbic acid (AA), on antibiofilm activity of $10 \mathrm{~b}$ with respect to planktonic cell adhesion, biofilm formation and mature biofilm $(48 \mathrm{~h})$ metabolic activity. Table 5 shows that $10 \mathrm{~b}+\mathrm{AA}$ or $10 \mathrm{~b}$ alone had no effect on planktonic cell adhesion although $10 \mathrm{~b}+\mathrm{AA}$ notably increased metabolic activity of planktonic cells compared to $10 \mathrm{~b}(P<0.01)$. No significant difference between $10 \mathrm{~b}+\mathrm{AA}$ and $10 \mathrm{~b}$ was found in inhibitory efficiency of biofilm formation despite the fact that $10 \mathrm{~b}+\mathrm{AA}$ markedly inhibited biofilm formation compared to AA $(P<0.01)$ (Table 6). 10b+AA significantly increased mature biofilm metabolic activity compared to $10 \mathrm{~b}(P<0.05)$ (Table 6). These results indicated that endogenous ROS augmentation generated by $10 \mathrm{~b}$ is a pivotal action mechanism to reduce mature biofilm metabolic activity, although elevated endogenous ROS have no impact upon biofilm formation and planktonic cell adhesion. To further verify above conclusion, XTT reduction assay was performed to investigate the effect of a well known ROS inducer MCZ on mature biofilm metabolic activity. As expected, MCZ at $10 \mu \mathrm{mol} / \mathrm{L}$ and $50 \mu \mathrm{mol} / \mathrm{L}$ markedly decreased mature biofilm metabolic activity and the inhibitory efficiency was $39.08 \%$ and $58.68 \%$, respectively, after $6 \mathrm{~h}$ exposure (Figure 6). Our data further confirmed a direct correlation between endogenous ROS augmentation and inhibition of mature biofilm metabolic activity.

\section{Discussion}

$10 \mathrm{~b}$ is a novel chemical structural antifungal agent with high antifungal activity, a broad antifungal spectrum and potentially low toxicity ${ }^{[3,37]}$. In this study, we found that $10 \mathrm{~b}$ 
Table 4. Genes up-regulated in 10b-grown biofilms compared to biofilms without treatment through two independent experiments.

\begin{tabular}{|c|c|c|c|c|c|}
\hline \multicolumn{6}{|l|}{ Translation } \\
\hline CAL0004848 & GAT2 & YMR136W & Transcription factor activity & 2.43 & 2.94 \\
\hline CAL0003471 & TEF4 & YKL081W & Putative translation elongation factor & 3.93 & 2.14 \\
\hline CAL0004558 & TEF2 & YBR118W & Translation elongation factor activity & 2.26 & 2.21 \\
\hline CAL0003667 & RPL20B & YMR242C & Predicted ribosomal protein & 2.25 & 2.11 \\
\hline CAL0005037 & RPL10A & YGL135W & Predicted ribosomal protein & 2.92 & 2.53 \\
\hline CAL0003534 & NAN1 & YPL126W & Positive regulation of transcription & 2.09 & 3.02 \\
\hline CAL0001506 & UBI3 & YLR167W & Structural constituent of ribosome & 2.31 & 2.09 \\
\hline CAL0004215 & SEN2 & YLR105C & tRNA-intron endonuclease activity & 3.07 & 3.57 \\
\hline \multicolumn{6}{|l|}{ RNA metabolic } \\
\hline CAL0002072 & GAR1 & YHR089C & Box H/ACA snoRNA binding & 2.32 & 2.75 \\
\hline CAL0001653 & CBF5 & YLR175W & Pseudouridylate synthase activity & 2.42 & 2.69 \\
\hline CAL0001648 & TRM3 & YDL112W & tRNA (guanine) methyltransferase activity & 2.34 & 2.72 \\
\hline CAL0002141 & TSR1 & YDL060W & rRNA processing & 2.26 & 3.16 \\
\hline CAL0005606 & RRP5 & YMR229C & Poly(U) RNA binding & 2.23 & 6.85 \\
\hline \multicolumn{6}{|l|}{ Transport } \\
\hline CAL0006337 & MEP1 & YPR138C & Ammonium transmembrane transporter activity & 3.70 & 4.47 \\
\hline CAL0001711 & VPS11 & YMR231W & Vacuolar protein sorting & 3.46 & 3.08 \\
\hline CAL0003818 & HGT17 & YNR072W & Putative glucose transporter & 3.77 & 4.59 \\
\hline CAL0001467 & HGT10 & YDR536W & Glycerol permease & 6.16 & 2.92 \\
\hline \multicolumn{6}{|c|}{ Hyphal or filamentous growth } \\
\hline CAL0002995 & NRG1 & YPR015C & Transcriptional repressor, regulates hyphal genes & 5.13 & 3.96 \\
\hline CAL0004265 & FGR29 & None & Filamentous growth regulator & 2.51 & 3.10 \\
\hline CAL0002268 & CZF1 & YDR207C & C albicans Zinc Finger protein, hyphal growth regulator & 2.89 & 4.33 \\
\hline \multicolumn{6}{|c|}{ ( } \\
\hline CAL0004825 & ULP1 & YPL020C & $\mathrm{G}_{2} / \mathrm{M}$ transition of mitotic cell cycle & 2.37 & 2.61 \\
\hline \multicolumn{6}{|c|}{ Lipid metabolic process } \\
\hline CAL0004027 & SLD1 & None & SphingoLipid delta-8 Desaturase & 5.12 & 9.78 \\
\hline CAL0006277 & FAD3 & None & Omega-3 fatty acid desaturase activity & 2.42 & 3.32 \\
\hline CAL0000316 & ERG9 & YHR190W & Farnesyl-diphosphate farnesyltransferase & 9.40 & 9.17 \\
\hline CAL0006397 & ERG6 & YML008C & Sterol 24-C-methyltransferase & 22.68 & 13.02 \\
\hline CAL0002665 & ERG5 & YMR015C & C-22 sterol desaturase & 7.65 & 26.93 \\
\hline CAL0001905 & ERG3 & YLR056W & C-5 sterol desaturase & 3.37 & 5.56 \\
\hline CAL0003306 & ERG27 & YLR100W & 3-keto sterol reductase & 2.98 & 5.53 \\
\hline CAL0005951 & ERG26 & YGL001C & C-3 sterol dehydrogenase (C-4 sterol decarboxylase) & 5.45 & 10.31 \\
\hline CAL0003665 & ERG251 & YGR060W & C-4 methylsterol oxidase & 10.11 & 16.52 \\
\hline CAL0001165 & ERG25 & YGR060W & C-4 methylsterol oxidase & 6.03 & 9.31 \\
\hline CAL0005685 & ERG24 & YNL280C & Delta14-sterol reductase & 6.08 & 6.95 \\
\hline CAL0005073 & $E R G 2$ & YMR202W & C-8 sterol isomerase & 31.41 & 18.07 \\
\hline CAL0004537 & ERG13 & YML126C & Hydroxymethylglutaryl-CoA synthase & 3.52 & 11.90 \\
\hline CAL0003627 & ERG11 & YHR007C & Lanosterol 14-alpha-demethylase & 7.74 & 16.75 \\
\hline CAL0005541 & ERG1 & YGR175C & Squalene epoxidase & 5.21 & 5.14 \\
\hline
\end{tabular}




\begin{tabular}{|c|c|c|c|c|c|}
\hline \multirow{2}{*}{$\begin{array}{l}\text { Primary } \\
\text { CGDID }\end{array}$} & \multirow[t]{2}{*}{ Gene name } & \multirow{2}{*}{$\begin{array}{c}\text { S cerevisiae } \\
\text { homologue name }\end{array}$} & \multirow[t]{2}{*}{ Function } & \multicolumn{2}{|c|}{ Change in fold expression } \\
\hline & & & & Ratio1 & Ratio2 \\
\hline \multicolumn{6}{|c|}{ Amino acid metabolic } \\
\hline CAL0002855 & $\mathrm{SAH1}$ & YER043C & S-adenosyl-L-homocysteine hydrolase & 3.95 & 4.90 \\
\hline CAL0004803 & ILV3 & YJR016C & Dihydroxy-acid dehydratase activity & 2.52 & 2.09 \\
\hline CAL0004920 & GCV2 & YMR189W & Glycine dehydrogenase (decarboxylating) activity & 2.02 & 8.86 \\
\hline CAL0006098 & GCV1 & YDR019C & T subunit of glycine decarboxylase & 2.25 & 9.99 \\
\hline CAL0002497 & CDC60 & YPL160W & Cytosolic leucyl tRNA synthetase & 2.08 & 2.36 \\
\hline CAL0006284 & SPE3 & YPR069C & Spermidine synthase activity & 2.48 & 2.11 \\
\hline CAL0002778 & UGA11 & YGR019W & 4-aminobutyrate transaminase activity & 2.31 & 2.11 \\
\hline CAL0006381 & IPF25064.1 & YJR070C & Deoxyhypusine monooxygenase activity & 2.06 & 5.86 \\
\hline \multicolumn{6}{|c|}{ Generation energy } \\
\hline \multicolumn{6}{|c|}{ Protein modification process } \\
\hline CAL0003800 & SET3 & YKR029C & NAD-dependent histone deacetylase activity & 5.07 & 3.84 \\
\hline \multicolumn{6}{|c|}{ Carbohydrate metabolic process } \\
\hline CAL0000604 & RHD1 & None & Putative beta-mannosyltransferase & 6.04 & 3.70 \\
\hline \multicolumn{6}{|l|}{ Cell stress } \\
\hline CAL0001195 & PGA23 & YFL067W & Putative GPI-anchored protein of unknown function & 2.61 & 3.60 \\
\hline CAL0003828 & DAG7 & None & Response to drug & 13.05 & 8.15 \\
\hline CAL0000509 & IMH3 & YML056C & Inosine monophosphate (IMP) dehydrogenase & 2.44 & 3.41 \\
\hline CAL0001161 & GPD2 & YDL022W & Intracellular accumulation of glycerol & 2.66 & 3.07 \\
\hline \multicolumn{6}{|l|}{ Cell adhesion } \\
\hline CAL0005516 & $A A F 1$ & YKL054C & Possible regulatory protein & 3.63 & 2.27 \\
\hline \multicolumn{6}{|l|}{ Not classified } \\
\hline CAL0003064 & IPF26046.1 & None & Unknown & 8.75 & 5.53 \\
\hline CAL0000188 & IPF19200.1 & YNR018W & Unknown & 6.14 & 5.01 \\
\hline CAL0000394 & IPF2997.1 & None & Unknown & 6.02 & 2.44 \\
\hline CAL0003899 & IPF27112.1 & YPR013C & Unknown & 5.77 & 15.00 \\
\hline CAL0001181 & IPF22876.1 & None & Unknown & 4.03 & 2.42 \\
\hline CAL0005757 & IPF20288.1 & None & Unknown & 3.41 & 4.38 \\
\hline CAL0001538 & AM01 & None & Unknown & 3.12 & 3.47 \\
\hline CAL0000702 & IPF9592.2 & YFL043C & Unknown & 3.11 & 3.35 \\
\hline
\end{tabular}

had strong anti-biofilm activity. To further investigate the action mechanism, cDNA microarray study was performed in C albicans SC5314 biofilms treated or untreated with $10 \mathrm{~b}$. The results of real-time RT-PCR showed that differentially expressed genes were involved in multiple biochemical functions. Our particular interest was the striking changes of biofilm formation related genes and energy-metabolism-related genes: glycolysis-related genes, fermentation-related genes and active oxygen scavenging-related genes.

It was found in this study that biofilm formation was directly related to striking down-regulation of ECE1 and marked up-regulation of NRG1. ECE1, a hypha-specific gene, is involved in the process of cell extension, the first morphological sign of which is the emergence of a germ tube approximately 90 min after induction ${ }^{[38]}$. Reports have confirmed that ECE1 promoter is strongly repressed by Nrg1p, a sequencespecific DNA-binding protein, under non-inducing conditions $^{[39,40]}$. Nrg1p, endoed by NRG1, plays important roles in the regulation of yeast-hyphal morphogenesis, and represses a subset of Tup1-regulated genes, including known hyphaspecific genes and other virulence factors. Most of these genes contain an Nrg1p response element (NRE) in their promoter. 


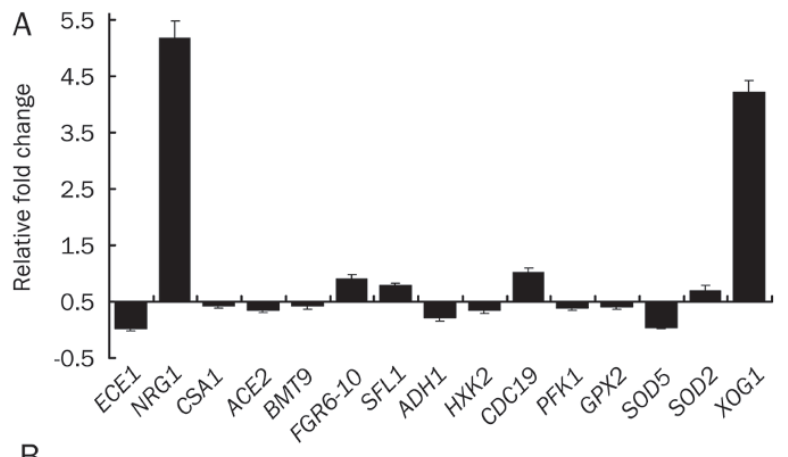

B

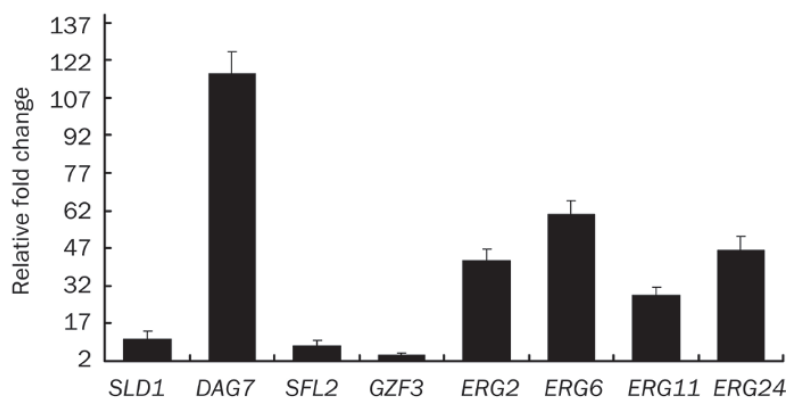

Figure 4. Gene expression changes in 25 genes of interest in $C$ albicans SC5314 biofilms treated with $10 \mathrm{~b}(10 \mu \mathrm{mol} / \mathrm{L})$ relative to untreatment: (A) genes related to the specific action mechanism of 10b; (B) genes independent of the action mechanism of $10 \mathrm{~b}$. All the genes were examined by real-time RT-PCR with gene-specific primers.

Nrg1p interacts specifically with an NRE in vitro ${ }^{[39]}$. Inactivation of Nrg1p in C albicans causes flamentous and invasive growth, derepresses hypha-specific genes and increases sensitivity to some stresses ${ }^{[39-41]}$. Our data indicate that striking down-regulation of ECE1 and marked up-regulation of NRG1 induced by $10 \mathrm{~b}$ might play a pivotal role during biofilm formation.
Another interesting result was the change of energymetabolism-related genes after $10 \mathrm{~b}$ treatment: global downregulation of glycolysis-related genes, fermentation-related genes and antioxidant defense genes. According to Pasteur effect that aerobic oxidation could inhibit glycolysis (alcoholfacient fermentation) under aerobic circumstances, the tricarboxylic acid cycling process might be enhanced following exposure to $10 \mathrm{~b}$ because expression of the genes participating in glycolysis especially encoding two rate-limiting enzymes genes, HXK2 and PFK1, was markedly decreased. Besides, expression of the gene encoded superoxide dismutase (SOD5) was also decreased. Together, endogenous ROS generation might be markedly augmented and experiment verified our deduce (data not shown). To determine whether endogenous ROS augmentation was the major mechanism of $10 \mathrm{~b}$ against $C$ albicans biofilms, we performed XTT reduction assay to investigate the effect of anti-oxidant AA on the anti-biofilm activity of $10 \mathrm{~b}$ and the effect of a well known ROS inducer $\mathrm{MCZ}$ on mature biofilm metabolic activity. Taken together, our results suggest that the mechanism of $10 \mathrm{~b}$ against mature biofilms is associated with the augmentation of endogenous ROS by affecting aerobic respiration in mitochondria.

Endogenous ROS, a natural byproduct of normal cellular metabolism, derives from mitochondrial respiratory chain electron leakage and plays important roles in cellular components damage and DNA cell signaling ${ }^{[42,43]}$. Reports have confirmed that increase of intracellular ROS production is involved in the mechanism of several antifungal agents ${ }^{[4,45]}$. Furthermore, it was found in our previous study that decreased endogenous ROS generation contributes to drug resistance of $C$ albicans ${ }^{[46]}$. However, the mechanisms by which Candida biofilms resist the action of antifungal agents are not known. In our present study, we found that the augmentation of endogenous ROS generated by $10 \mathrm{~b}$ significantly reduced mature biofilm metabolic activity, and when the augmentation endogenous ROS is scavenged after addition of anti-oxidant

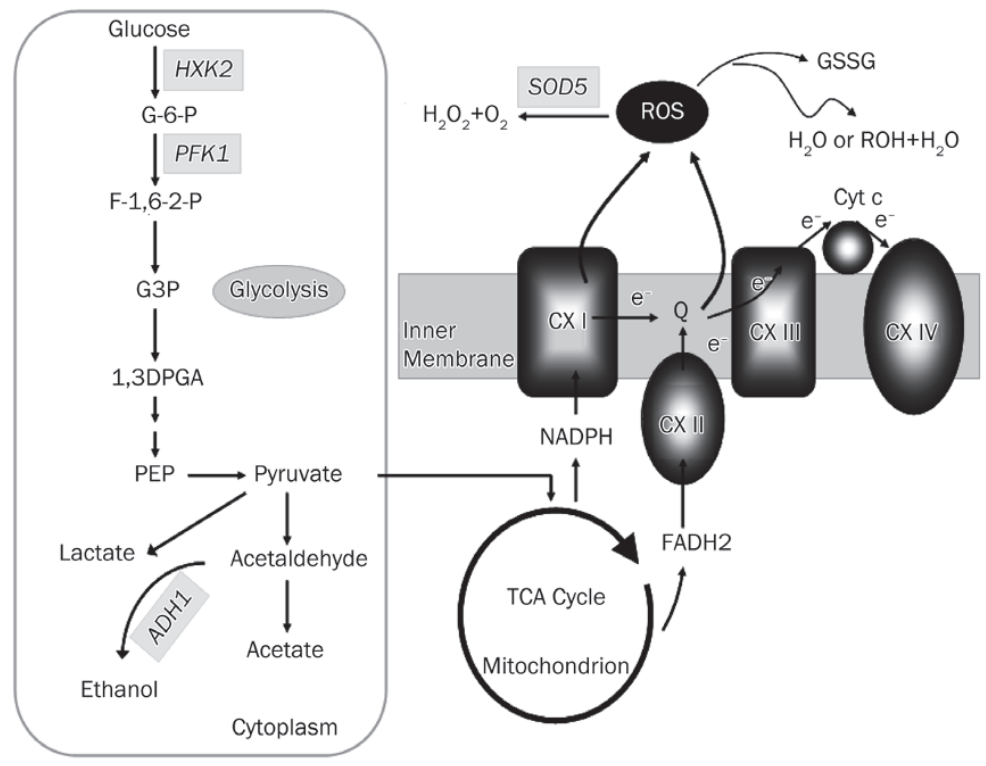

Figure 5. Central carbon metabolism in $C$ albicans biofilms during aerobic growth on glucose. The gray ellipses indicate low expression of genes encoded metabolic enzymes participated in aerobic oxidation process after treatment with $10 \mathrm{~b}$. The black ellipses indicate augmented tricarboxylic acid cycling process and endogenous reactive oxygen species generation after treatment with 10b. G-6-P, glucose-6-phosphate; F-1,6-2P, fructose-1,6-bisphosphate; G3P, glyceraldehyde-3-phosphate; 1,3-DPGA, 1,3-bisphosphoglycerate; PEP, phosphoenolpyruvate; TCA cycle, tricarboxylic acid cycle. 
Table 5. Effect of $10 \mathrm{~b}$ combined ascorbic acid (AA) on $C$ albicans planktonic cells adhesion.

\begin{tabular}{|c|c|c|c|c|c|}
\hline \multirow[t]{2}{*}{ Treatment with PBS } & \multicolumn{5}{|c|}{ XTT reduction $(\%)^{a)}$ in medium containing $10 \mathrm{~b}$ and/or ascorbic acid at the concentration of: } \\
\hline & $10 b$ & $10 \mathrm{~b}+\mathrm{AA}(5 \mathrm{mmol} / \mathrm{L})$ & $10 \mathrm{~b}+\mathrm{AA}(10 \mathrm{mmol} / \mathrm{L})$ & $\mathrm{AA}(5 \mathrm{mmol} / \mathrm{L})$ & $\mathrm{AA}(10 \mathrm{mmol} / \mathrm{L})$ \\
\hline None wash & $51.61 \pm 2.41$ & $81.29 \pm 4.81^{\mathrm{ce}}$ & $116.67 \pm 8.76^{\mathrm{ce}}$ & $124.85 \pm 8.65$ & $184.94 \pm 23.96$ \\
\hline Wash twice & $92.54 \pm 2.82$ & $93.53 \pm 2.55$ & $108.46 \pm 5.04$ & $118.11 \pm 2.80$ & $122.10 \pm 10.86$ \\
\hline
\end{tabular}

a) C albicans SC5314 planktonic cells containing $10 \mathrm{~b}$ at $10 \mu \mathrm{mol} / \mathrm{L}$ combined 5, and/or $10 \mathrm{mmol} / \mathrm{L}$ ascorbic acid (AA) was incubated for 90 min at $37{ }^{\circ} \mathrm{C}$. XTT reduction is expressed as a percentage of that of control. The results are mean \pm standard deviations of three independent experiments. Mean \pm standard error of the mean values $\left(A_{492}\right)$ for the controls were $0.226 \pm 0.031$ without PBS treatment and $0.134 \pm 0.019$ with $P B S$ washing twice. ${ }^{\mathrm{c}} P<0.01$ vs $10 \mathrm{~b}$ alone. ${ }^{\mathrm{e}} P<0.05$ vs $\mathrm{AA}$ alone.

Table 6. Effect of ascorbic acid (AA) on the inhibition of $10 \mathrm{~b}$ against $C$ albicans biofilm formation and mature biofilm (48 h).

\begin{tabular}{|c|c|c|c|c|c|}
\hline \multirow[b]{2}{*}{ Growth situation } & \multicolumn{5}{|c|}{ XTT reduction $(\%)^{\mathrm{a})}$ in medium containing $10 \mathrm{~b}$ and/or ascorbic acid at the concentration of: } \\
\hline & $10 \mathrm{~b}$ & $10 \mathrm{~b}+\mathrm{AA}(5 \mathrm{mmol} / \mathrm{L})$ & $10 \mathrm{~b}+\mathrm{AA}(10 \mathrm{mmol} / \mathrm{L})$ & AA (5 mmol/L) & $\mathrm{AA}(10 \mathrm{mmol} / \mathrm{L})$ \\
\hline Biofilm formation ${ }^{\text {b) }}$ & $48.35 \pm 2.67$ & $52.61 \pm 3.28^{f}$ & $51.19 \pm 4.20^{f}$ & $94.33 \pm 5.26$ & $103.36 \pm 3.24$ \\
\hline Mature biofilm (48 h) ${ }^{c}$ & $72.47 \pm 5.04$ & $84.41 \pm 4.05^{\text {be }}$ & $86.22 \pm 3.28^{\text {be }}$ & $101.07 \pm 5.90$ & $98.03 \pm 2.86$ \\
\hline
\end{tabular}

a) XTT reduction is expressed as a percentage of that of control biofilms. ${ }^{\text {b) }} 10 \mathrm{~b}$ at $10 \mu \mathrm{mol} / \mathrm{L}$ combined 5 and/or $10 \mathrm{mmol} / \mathrm{L}$ AA were added to culture of yeasts following the initial $1 \mathrm{~h}$ adhesion and incubated for $48 \mathrm{~h}$ at $37^{\circ} \mathrm{C}$. $\left.{ }^{\circ}\right) 10 \mathrm{~b}$ at $10 \mu \mathrm{mol} / \mathrm{L} \mathrm{combined} 5$ and/or $10 \mathrm{mmol} / \mathrm{L} \mathrm{AA} \mathrm{were} \mathrm{added} \mathrm{to} \mathrm{mature}$ $(48 \mathrm{~h})$ biofilms grown in the absence of the drugs, and incubation was continued for a further $6 \mathrm{~h}$ at $37^{\circ} \mathrm{C}$. The results are mean \pm standard deviations of three independent experiments. ${ }^{\mathrm{b}} P<0.05$ vs $10 \mathrm{~b}$ alone; ${ }^{\mathrm{e}} P<0.05,{ }^{\mathrm{f}} P<0.01$ vs AA alone.

AA, mature biofilm metabolic activity increased markedly. Our data indicate that ROS augmentation might be a major mechanism of $10 \mathrm{~b}$ against $C$ albicans mature biofilms. This was confirmed by a well known ROS inducer MCZ, which was able to markedly reduce mature biofilm metabolic activity at $10 \mu \mathrm{mol} / \mathrm{L}$.

Drug binding assays and cell wall component modification studies suggest that cell wall changes may contribute to antifungal biofilm drug resistance ${ }^{[13]}$. Beta-1,3-glucan is the major structural polysaccharide of the fungal cell wall and is thought to be the main component of the three-dimensional

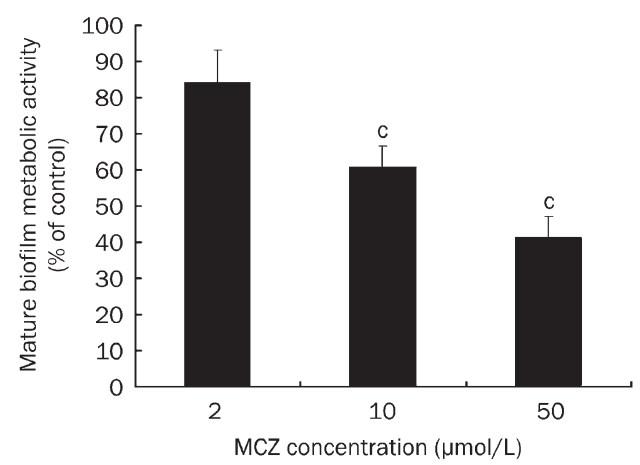

Figure 6. Effect of MCZ incubated for $6 \mathrm{~h}$ on mature $(48 \mathrm{~h})$ biofilms. MCZ was added to mature ( $48 \mathrm{~h})$ biofilms and incubation was continued for $6 \mathrm{~h}$ at $37^{\circ} \mathrm{C}$. XTT reduction is expressed as a percentage of that of control mature biofilms $(48 \mathrm{~h})$ further incubated for $6 \mathrm{~h}$. The results are mean \pm standard deviations of three independent experiments. Statistically significant differences as determined by Student's $t$ test. ${ }^{\mathrm{b}} P<0.05,{ }^{\mathrm{c}} \mathrm{P}<0.01$ vs control. matrix surrounding biofilm cells and closely tied to biofilm formation ${ }^{[47]}$. In our study, we found that expression of gene XOG1, encoding exo-1,3-beta-glucanase enzyme, increased dramatically. This indicated that up-regulated XOG1 might be another pathway to inhibit biofilm formation because exo-1,3beta-glucanase enzyme specifically hydrolyzes beta- 1,3 glucan, resulting in destruction of the matrix of $C$ albicans biofilms and cell wall ${ }^{[48]}$.

In conclusion, the results of the present study show that $10 \mathrm{~b}$ treatment altered the expression of biofilm formation-related genes, impaired the ability of $C$ albicans to change its morphology, decreased beta- 1,3 glucan levels in the biofilm matrix and cell wall, and ultimately blocked $C$ albicans to form mature biofilms. In addition, mitochondrial aerobic respiration shift and endogenous ROS augmentation also contributed to reducing mature biofilm metabolic activity. This might provide useful information for the development of new strategies to reduce the incidence of device-associated infections.

\section{Acknowledgements}

We thank Dr William A FONZI for kindly offering the isolate C albicans SC5314 in this study.

This work was supported by the National Natural Science Foundation of China (30825041, 30500628, and 30630071), National Basic Research Project (2005CB523105), National High Technology Research and Development Program 863 of China (2008AA02Z302).

\section{Author contribution}

Yuan-ying JIANG and Yong-bing CAO designed research; Rong-mei LIANG performed the research and wrote the 
paper; You-jun ZHOU and Hui TANG synthesized 10b; Yi XU, Ping-hui GAO, Bao-di DAI and Feng YANG critically read the manuscript.

\section{References}

1 Ramage G, Saville SP, Wickes BL, Lopez-Ribot JL. Inhibition of Candida albicans biofilm formation by farnesol, a quorum-sensing molecule. Appl Environ Microbiol 2002; 68: 5459-63.

2 Sato T, Watanabe T, Mikami T, Matsumoto T. Farnesol, a morphogenetic autoregulatory substance in the dimorphic fungus Candida albicans, inhibits hyphae growth through suppression of a mitogenactivated protein kinase cascade. Biol Pharm Bull 2004; 27: 751-2.

3 Nett J, Ande D. Candida albicans biofilm development, modeling a host-pathogen interaction. Curr Opin Microbiol 2006; 9: 340-5.

4 Izano EA, Sadovskaya I, Vinogradov E, Mulks MH, Velliyagounder K, Ragunath C. Poly-N-acetylglucosamine mediates biofilm formation and antibiotic resistance in Actinobacillus pleuropneumoniae. Microb Pathog 2007; 43: 1-9.

5 Oliveira M, Nunes SF, Carneiro C, Bexiga R, Bernardo F, Vilela CL. Time course of biofilm formation by Staphylococcus aureus and Staphylococcus epidermidis mastitis isolates. Vet Microbiol 2007; 124: 187-91.

6 Wang C, Li M, Dong D, Wang J, Ren J, Otto M, et al. Role of ClpP in biofilm formation and virulence of Staphylococcus epidermidis. Microbes Infect 2007; 9: 1376-83.

7 Andes D, Nett J, Oschel P, Albrecht R, Marchillo K, Pitula A. Development and characterization of an in vivo central venous catheter Candida albicans biofilm model. Infect Immun 2004; 72: 6023-31.

8 Chandra J, Kuhn DM, Mukherjee PK, Hoyer LL, McCormick T, Ghannoum MA. Biofilm formation by the fungal pathogen Candida albicans: development, architecture, and drug resistance. J Bacteriol 2001; 183: 5385-94.

9 Baillie GS, Douglas $\sqcup$. Matrix polymers of Candida biofilms and their possible role in biofilm resistance to antifungal agents. J Antimicrob Chem 2000; 46: 397-403.

10 Baillie GS, Douglas LJ. Effect of growth rate on resistance of Candida albicans biofilms to antifungal agents. Antimicrob Agents Chemother 1998; 42: 1900-5.

11 Baillie GS, Douglas $\sqcup$. Iron-limited biofilms of Candida albicans and their susceptibility to amphotericin B. Antimicrob Agents Chemother 1998; 42: 2146-9.

12 Nobile1 CJ, Nett JE, Hernday AD, Homann OR, Deneault JS, Nantel A, et al. Biofilm matrix regulation by Candida albicans Zap1. PLoS Biol 2009; 7: e1000133.

13 Nett J, Lincoln L, Marchillo K, Massey R, Holoyda K, Hoff B, et al. Putative role of beta-1,3 glucans in Candida albicans biofilm resistance. Antimicrob Agents Chemother 2007; 51: 510-20.

14 Liu H. Transcriptional control of dimorphism in Candida albicans. Curr Opin Microbiol 2001; 4: 728-35.

15 Liu H, Kohler J, Fink GR. Suppression of hyphal formation in Candida albicans by mutation of a STE12 homolog. Science 1994; 266: 1723-6.

16 Staab JF, Bradway SD, Fidel PL, Sundstrom P. Adhesive and mammalian Transglut aminase substrate properties of Candida albicans Hwp1. Science 1999; 283: 1535-38.

17 Bailey DA, Feldmann PJF, Bovey M, Gow NAR, Brown AJP. The Candida albicans HYR1 gene, which is activated in response to hyphal development, belongs to a gene family encoding yeast cell wall proteins. J Bacteriol 1996; 178: 5353-60.

18 Birse CE, Irwin MY, Fonzi WA, Sypherd PS. Cloning and characteriza- tion of ECE1, a gene expressed in association with cell elongation of the dimorphic pathogen Candida albicans. Infect Immun 1993; 61: 3648-55.

19 Calderone RA, Fonzi WA. Virulence factors of Candida albicans. Trends Microbiol 2001; 9: 327-35.

20 Hoyer LL. The ALS gene family of Candida albicans. Trends Microbiol 2001; 9: 176-80.

21 Zheng X, Wang YM, Wang Y. Hgc1, a novel hypha-specific G1 cyclinrelated protein regulates Candida albicans hyphal morphogenesis. EMBO J 2004; 23: 1845-56.

22 Braun BR, Johnson AD. Control of filament formation in Candida albicans by the transcriptional repressor TUP1. Science 1997; 277: 105-9.

23 Braun BR, Kadosh D, Johnson AD. NRG1, a repressor of filamentous growth in Candida albicans, is down-regulated during filament induction. EMBO J 2001; 20: 4753-61.

24 Li YD, Su C, Mao XM, Cao F, Chen JY. Roles of Candida albicans Sfl1 in hyphal development. Eukaryotic Cell 2007; 6: 2112-21.

25 Kadosh D, Johnson AD. Rfg1, a protein related to the S. cerevisiae hypoxic regulator Rox1, controls filamentous growth and virulence in $C$ albicans. Mol Cell Biol 2001; 21: 2496-505.

26 Kadosh D, Johnson AD. Induction of the Candida albicans filamentous growth program by relief of transcriptional repression: a genome-wide analysis. Mol Biol Cell 2005; 16: 2903-12.

27 Nickerson KW, Atkin AL, Hornby JM. Quorum sensing in dimorphic fungi: farnesol and beyond. Appl Environ Microbiol 2006; 72: 380513.

28 Hornby JM, Jensen EC, Lisec AD, Tasto JJ, Jahnke B, Shoe-maker R, et al. Quorum sensing in the dimorphic fungus Candida albicans is mediated by farnesol. Appl Environ Microbiol 2001; 67: 2982-92.

29 Jain N, Kohli R, Cook E, Gialanella P, Chang T, Fries BC. Biofilm formation by and antifungal susceptibility of Candida isolates from urine. Appl Environ Microbiol 2007; 73: 1697-703.

30 Jin Y, Samaranayake LP, Samaranayake Y, Yip HK. Biofilm formation of Candida albicans is variably affected by saliva and dietary sugars. Arch Oral Biol 2004; 49: 789-98.

31 Cao YY, Dai BD, Wang Y, Huang S, Xu YG, Cao YB, et al. In vitro activity of baicalein against Candida albicans biofilms. Int J Antimicrob Agents 2008; 32: 73-7.

32 Kohrer K, Domdey H. Preparation of high molecular weight RNA. Methods Enzymol 1991; 194: 398-405.

33 Patterson TA, Lobenhofer EK, Fulmer-Smentek SB, Collins PJ, Chu TM, Bao W, et al. Performance comparison of one-color and two-color platforms within the Microarray Quality Control (MAQC) project. Nat Biotech 2006; 24: 1140-50.

34 Eklund AC, Turner LR, Chen P, Jensen RV, Defeo G, Kopf-Sill AR, et al. Replacing CRNA targets with CDNA reduces microarray crosshybridization. Nat Biotechnol 2006; 24: 1071-73.

35 Yang YH, Dudoit S, Luu P, Lin DM, Peng V, Ngai J, et al. Normalization for cDNA microarray data: a robust composite method addressing single and multiple slide systematic variation. Nucleic Acids Res 2002; 30: e15.

36 Yao B, Ji HT, Cao YB, Zhou YJ, Zhu J, Lu JG, et al. Synthesis and antifungal activities of novel 2-aminotetralin derivatives. J Med Chem 2007; 50: 5293-300.

37 Liang RM, Cao YB, Fan KH, Xu Y, Gao PH, Zhou YJ, et al. 2-Aminononyl-6-meth-oxyl-tetralin muriate inhibits sterol $\mathrm{C}$-14 reductase in the ergosterol biosynthetic pathway. Acta Pharmacol Sin 2009; 30: 1709-16.

38 Calderone RA, Fonzi WA. Virulence factors of Candida albicans. Trends Microbiol 2001; 9: 327-35. 
39 Murad AM, Leng P, Straffon M, Wishart J, Macaskill S, MacCallum DM, et al. NRG1 represses yeast-hypha morphogenesis and hypha-specific gene expression in Candida albicans. EMBO J 2001; 20: 4742-52.

40 Braun BR, Kadosh D, Johnson AD. NRG1, a repressor of filamentous growth in Candida albicans, is down-regulated during filament induction. EMBO J 2001; 20: 4753-61.

41 Moran GP, MacCallum DM, Spiering MJ, Coleman1 DC, Sullivan DJ. Differential regulation of the transcriptional repressor NRG1 accounts for altered host-cell interactions in Candida albicans and Candida dubliniensis. Mol Microbiol 2007; 66: 915-29.

42 Brookes PS, Darley-Usmar VM. Hypothesis: the mitochondrial NO signaling pathway and the transduction of nitrosative to oxidative cell signals: an alternative function for cytochrome $c$ oxidase. Free Radic Biol Med 2002; 32: 370-4.

43 Brookes PS, Levonen AL, Shiva S, Sarti P, Darley-Usmar VM. Mitochondria: regulators of signal transduction by reactive oxygen and nitrogen species. Free Radic Biol Med 2002; 33: 755-64.
44 Kobayashi D, Kondo K, Uehara N, Otokozawa S, Tsuji N, Yagihashi A, et al. Endogenous reactive oxygen species is an important mediator of miconazole antifungal effect. Antimicrob Agents Chemother 2002; 46: 3113-7.

45 Kontoyiannis DP. Modulation of fluconazole sensitivity by the interaction of mitochondria and erg3p in Saccharomyces cerevisiae. J Antimicrob Chemother 2000; 46: 191-7.

46 Yan L, Zhang JD, Cao YB, Gao PH, Jiang YY. Proteomic analysis reveals a metabolism shift in a laboratory fluconazole-resistant Candida albicans strain. J Proteome Res 2007; 6: 2248-56.

47 Nobile1 CJ, Nett JE, Hernday AD, Homann OR, Deneault JS, Nantel A, et al. Biofilm matrix regulation by Candida albicans zap1. PLoS Biol 2009; 7: e1000133.

48 Humphreys AM, Gooday GW. Properties of chitinase activities from Mucor mucedo: evidence for a membrane-bound zymogenic form. J Gen Microbiol 1984; 130: 1359-66. 